\title{
Agenesis treatment with osseointegrated implant and filling of the buccal bone plate
}

\section{with biomaterial}

\author{
Tratamento de agenesia com implante osseointegrado e preenchimento da tábua óssea vestibular \\ com biomaterial \\ Tratamiento de agenesia com implante osteointegrado y relleno de la placa óssea vestibular com \\ biomaterial
}

\author{
Ana Maira Pereira Baggio \\ ORCID: https://orcid.org/0000-0002-9474-5091 \\ Paulista State University, Brazil \\ E-mail: anamairabaggio@gmail.com \\ Aimée Maria Guiotti \\ ORCID: https://orcid.org/0000-0001-8903-6138 \\ Paulista State University, Brazil \\ E-mail: aimee.m.guiotti@ unesp.br \\ Juliano Milanezi de Almeida \\ ORCID: https://orcid.org/0000-0002-5995-5747 \\ Paulista State University, Brazil \\ E-mail: juliano.milanezi@unesp.br \\ Stéfani Caroline Ferriolli \\ ORCID: https://orcid.org/0000-0003-0019-6026 \\ Paulista State University, Brazil \\ E-mail:stefani.ferriolli@outlook.com \\ Izabela Fornazari Delamura \\ ORCID: https://orcid.org/0000-0001-8046-489X \\ Paulista State University, Brazil \\ E-mail:izabela.delamura@unesp.br \\ Ana Paula Farnezi Bassi \\ ORCID: https://orcid.org/0000-0002-0031-4953 \\ Paulista State University, Brazil \\ E-mail:ana.bassi@unesp.br
}

\begin{abstract}
Dental agenesis consists of an anomaly characterized by the numerical reduction of dental elements and, according to the number of missing teeth, it may receive other names, such as hypodontia, oligodontia, anodontia or congenital absence. Several treatments may be recommended depending on the patient's needs and conditions, such as surgery for the installation of implants and fixed prostheses, and early diagnosis is one of the key parts for proper treatment. The rehabilitation of agenesis of the upper lateral incisor is a great challenge for the professional since several factors can influence the aesthetic result and, in addition, the absence of the dental element can bring unbalance of the occlusion and phonetic problems. It is essential to carry out an adequate planning and a treatment plan with multidisciplinary action so that the final result is effective and meets the expectations of each patient. The present study aimed to report a clinical case of dental agenesis of the upper lateral incisor, where the treatment of choice was the installation of an implant-supported prosthesis and filling of the buccal bone plate with biomaterial.
\end{abstract}

Keywords: Anodontia; Dental implants; Biocompatible materials.

\section{Resumo}

A agenesia dentária consiste em uma anomalia caracterizada pela redução numérica dos elementos dentários e de acordo com o número de dentes faltantes pode receber outras denominações, como hipodontia, oligodontia, anodontia ou ausência congênita. Diversos tratamentos podem ser preconizados dependendo da necessidade e condições do paciente, como cirurgia para instalação de implantes e próteses fixas, sendo que o diagnóstico precoce é uma das peças-chaves para o tratamento adequado. A reabilitação de agenesia de incisivo lateral superior é um grande desafio para o profissional visto que diversos fatores podem influenciar no resultado estético e além disso, a ausência do elemento dental pode trazer desequilíbrio da oclusão e problemas fonéticos. É fundamental a realização de um planejamento adequado e um plano de tratamento com ação multidisciplinar para que o resultado final seja efetivo e supra as expectativas de cada paciente. O presente trabalho objetivou relatar um caso clínico de agenesia dental de 
incisivo lateral superior, onde o tratamento de escolha foi a instalação de uma prótese implantossuportada e preenchimento da tábua óssea vestibular com biomaterial.

Palavras-chave: Anodontia; Implantes dentários; Materiais biocompatíveis.

\section{Resumen}

La agenesia dental consiste en una anomalía caracterizada por la reducción numérica de elementos dentarios y, según el número de dientes faltantes, puede recibir otros nombres, como hipodoncia, oligodoncia, anodoncia o ausencia congénita. Se pueden recomendar varios tratamientos en función de las necesidades y condiciones del paciente, como la cirugía para la instalación de implantes y prótesis fijas, y el diagnóstico precoz es una de las piezas clave para un tratamiento adecuado. La rehabilitación de la agenesia del incisivo lateral superior es un gran reto para el profesional ya que varios factores pueden influir en el resultado estético y, además, la ausencia del elemento dental puede traer desequilibrio de la oclusión y problemas fonéticos. Es fundamental llevar a cabo una adecuada planificación y un plan de tratamiento con acción multidisciplinar para que el resultado final sea efectivo y cumpla con las expectativas de cada paciente. El presente estudio tuvo como objetivo reportar un caso clínico de agenesia dental del incisivo lateral superior, donde el tratamiento de elección fue la instalación de una prótesis implantosoportada y el relleno de la placa ósea vestibular con biomaterial.

Palabras clave: Anodoncia; Implantes dentales; Materiales biocompatibles.

\section{Introduction}

Dental agenesis is a relatively common anomaly in human dentition, characterized by the absence of one or more teeth, which causes a great aesthetic and functional impact on the individual's life. The lack of a dental element can directly interfere with occlusion and, consequently, with functions such as swallowing and phonetics, in addition to providing great discomfort and undesirable aesthetics (Salgado et al., 2012; Polder et al., 2004; Elerat et al., 2010).

Regarding its etiology, it is still widely discussed and there are controversies in the literature, being pointed out as multifactorial. Agenesis may be associated with genetic factors or isolated phenomena such as endocrine changes, pathologies, infections such as rubella and syphilis, chemotherapy and facial trauma, which trigger disturbances in the stages of initiation and proliferation during odontogenesis resulting in the absence of one or more dental elements (Salgado et al., 2012; Polder et al., 2004; Moyers, 1991; Nagem Filho et al., 2008).

As for prevalence, dental agenesis affects 1.37 times more women than men, with third molars being affected more frequently, followed by lower second premolars, upper lateral incisors and upper second premolars, which may vary. according to the population studied (Polder et al., 2004; Moyers, 1991; Pinho et al., 2005; Nagem Filho et al., 2008).

According to the number of teeth missing in the dental arch, agenesis, also defined as congenital absence, may receive other names. The absence of one to six dental elements is called hypodontia, while the absence of more than six teeth is classified as oligodontics, and the complete absence of teeth is called anodontia. The lack of one or two teeth is the most common finding, and the unilateral absence of an upper lateral incisor is often associated with malformation of the contralateral lateral incisor, with microdontia being the most frequent anomaly in these cases (Pinho et al., 2005; Coelho Terra et al., 2011; Elerat et al., 2010).

The diagnosis is made through clinical and radiographic examinations, and the sooner the anomaly is identified, the more favorable the prognosis will be, since the treatment options will be greater (Elerat et al., 2010; Nagem Filho et al., 2008; Tanaka et al., 2012).

In order to meet the patient's expectations and obtain a final result with good predictability, it is essential that the dental surgeon has a multidisciplinary view to carry out the most appropriate planning and treatment plan for each case, respecting the indications and limitations each patient. Therefore, planning a case of dental agenesis is often considered a major challenge for the professional, since the treatment must aim to restore not only the functional, but also the patient's aesthetic (Salgado et al., 2012; Elerat et al., 2010; Nagem Filho et al., 2008; Tanaka et al., 2012). 
Viable treatment options include specialties such as Periodontics, Dentistry, Prosthesis, Implantology and Orthodontics. The opening or maintenance of the space can be performed through orthodontic treatment for later replacement of missing teeth with the installation of osseointegrated implants or prosthetic rehabilitation. Another alternative is to close the spaces with aesthetic resuscitation of the adjacent tooth. In the case of agenesis of the lateral incisor, resuscitation of the canine can be performed, transforming it into a lateral incisor. Among the prosthetic options are the removable prosthesis, conventional fixed prosthesis or implant-supported fixed prosthesis (Salgado et al., 2012; Pinho et al., 2005; Coelho Terra et al., 2011; Elerat et al., 2010; Nagem Filho et al., 2008; Tanaka et al., 2012).

Implantology has become one of the most viable and highly successful options in recent years. However, bone limitations, such as deficiency of buccal-lingual bone tissue, represent challenges for rehabilitation with implants. Thus, the use of biomaterials that assist in the bone repair process and the performance of reconstructive techniques such as grafting, are gaining more and more space. Among the biomaterials most used today we can mention hydroxyapatite, mineralized or demineralized bone, bioactive glass, etc. (Mazaro et al., 2014; Tsuda et al., 2011; Chen et al., 2014; Pilger et al., 2018; Miron et al., 2016).

\section{Methodology}

This study is a case report in a qualitative and descriptive way (Pereira et al., 2018), bringing relevant data from the literature regarding the treatment of dental agenesis through the installation of a fixed implant-supported prosthesis in the region of the element 22 and filling the region of the vestibular bone plate with particulate bone to obtain adequate bone thickness. The ethical principles of the Declaration of Helsinki were respected and the patient signed the "Termo de Consentimento Livre e Esclarecido (TCLE)" to participate in the research.

\section{Case Report}

Female patient 21 years old, with agenesis of element 22, attended the clinic of the Faculty of Dentistry of Araçatuba complaining about the aesthetics of the removable partial denture installed more than 10 years ago to supply the absence of the dental element. After performing the clinical and radiographic exams, we opted for rehabilitation with an osseointegrated implant, however it was found that the patient had insufficient vestibular bone plate. It was then decided to fill the region with deproteinized bovine mineral bone (Geistlich Bio-Oss ${ }^{\circledR}$ ) in the respective surgical bed. Figure 1 shows the patient's initial intraoral clinical appearance. 
Figure 1 - Initial intraoral clinical aspect.

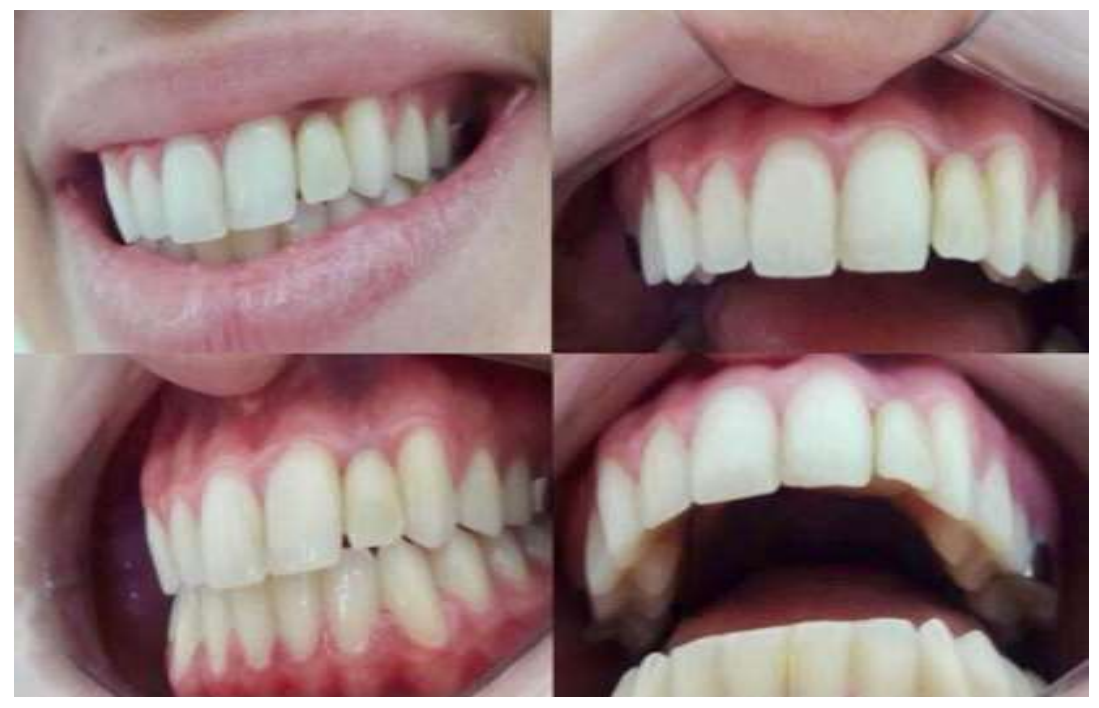

Source: Authors.

Figure 1 shows the initial intra-oral clinical aspect, showing the removable prosthesis and a certain bulging in the middle and apical third of the vestibular bone plate in the region of the element 22, which was significantly contributing to the patient's smile esthetics, causing her dissatisfaction. After clinical and radiographic evaluation and the patient's consent, the team opted to install an osseointegrated implant of the Morse Cone type (3.5 x $10 \mathrm{~mm}$ - Neodent $\left.{ }^{\circledR}\right)$ and then fill the region with biomaterial (Bio-Oss $®$ ) for that bone neoformation could occur in the region, reestablish the papillary anatomy and obtain a harmonic contour of the gingival margin.

The surgical step was performed after the removal of the old prosthesis that the patient used. The surgical procedure started with infiltrative anesthesia of the region of the alveolar crest and terminal infiltrative anesthesia of the anterior and middle alveolar nerve, followed by incision, detachment and flap folding to perform the reamings following the implant installation protocol (Figure 2). Subsequently, the particulate bone was placed in position as shown in Figure 3.

Figure 2- Cone Morse Implant 3.5 x $10 \mathrm{~mm}$.

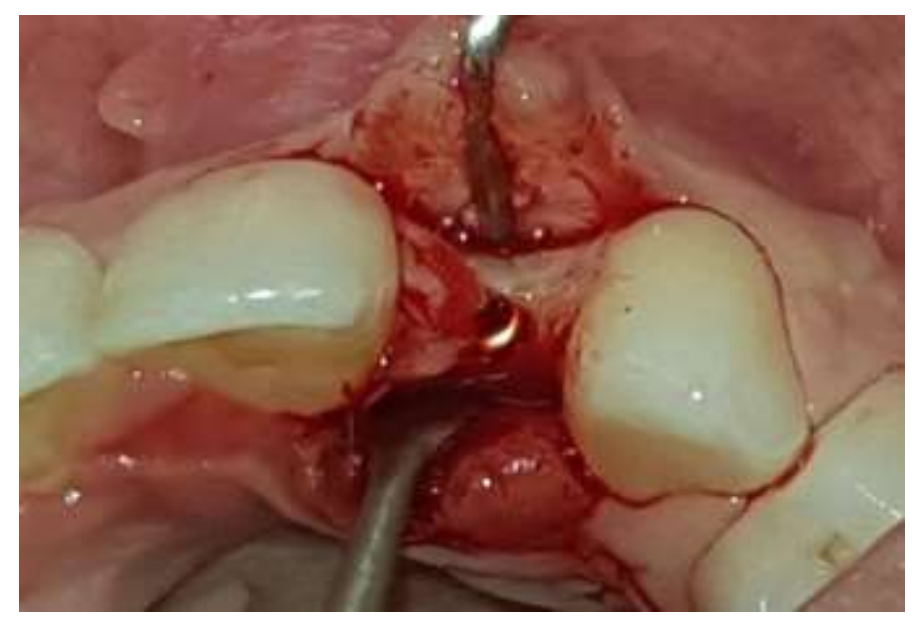

Source: Authors.

Figure 2 shows the implant in position and the removal of soft tissues from the peri-implant region for filling the vestibular bone plate with biomaterial. 
Figure 3-Filling the region with biomaterial (Bio-oss $\left.{ }^{\circledR}\right)$.

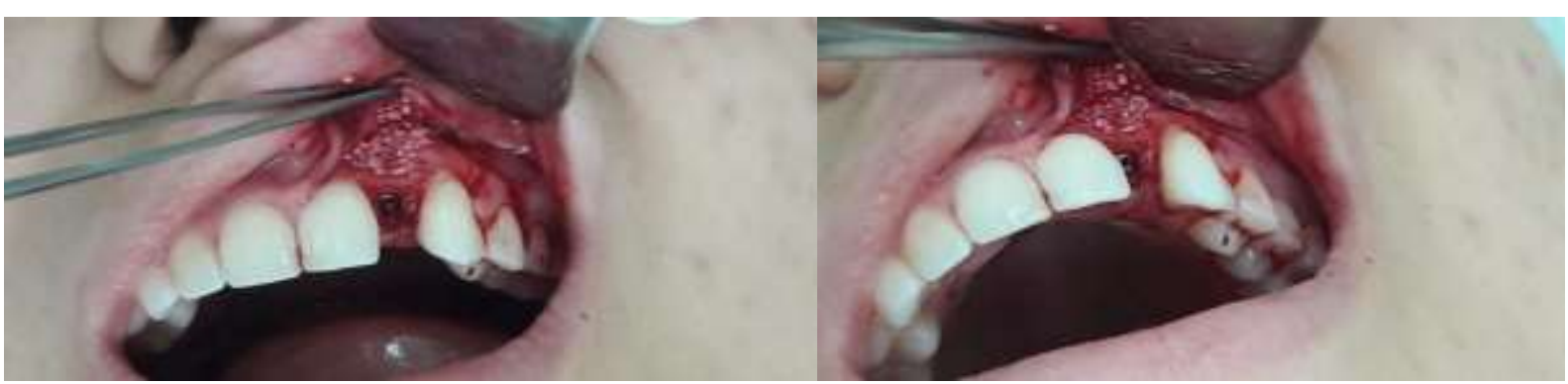

Source: Authors.

Figure 3 illustrates the filling of the region with deproteinized bovine mineral bone. Then, the flaps were carefully repositioned and sutured with Seda 4.0 thread, as shown in Figure 4.

Figure 4- Suture.

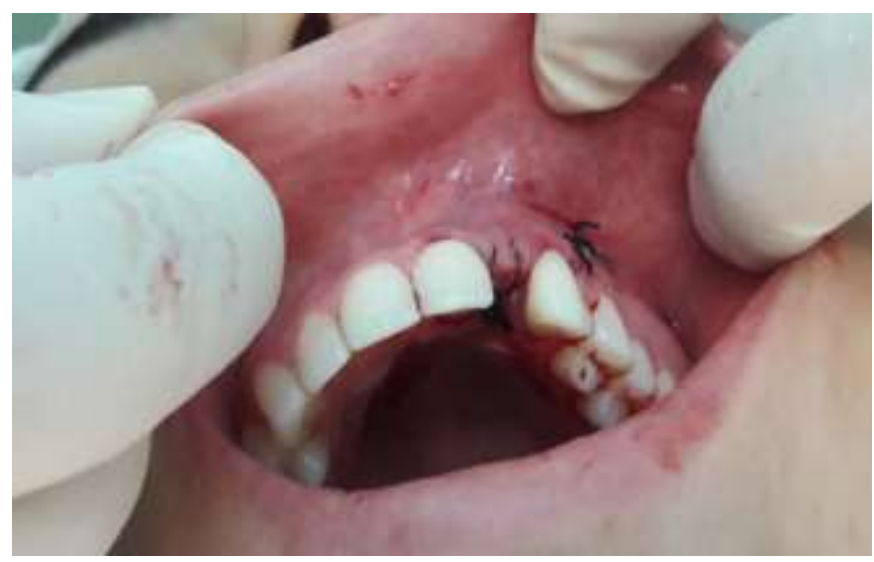

Source: Authors.

After 8 months, the patient returned with excellent healing of the region and a connective tissue graft was performed in the region, as shown in Figure 5.

Figure 5- 8 months postoperative and connective tissue graft.

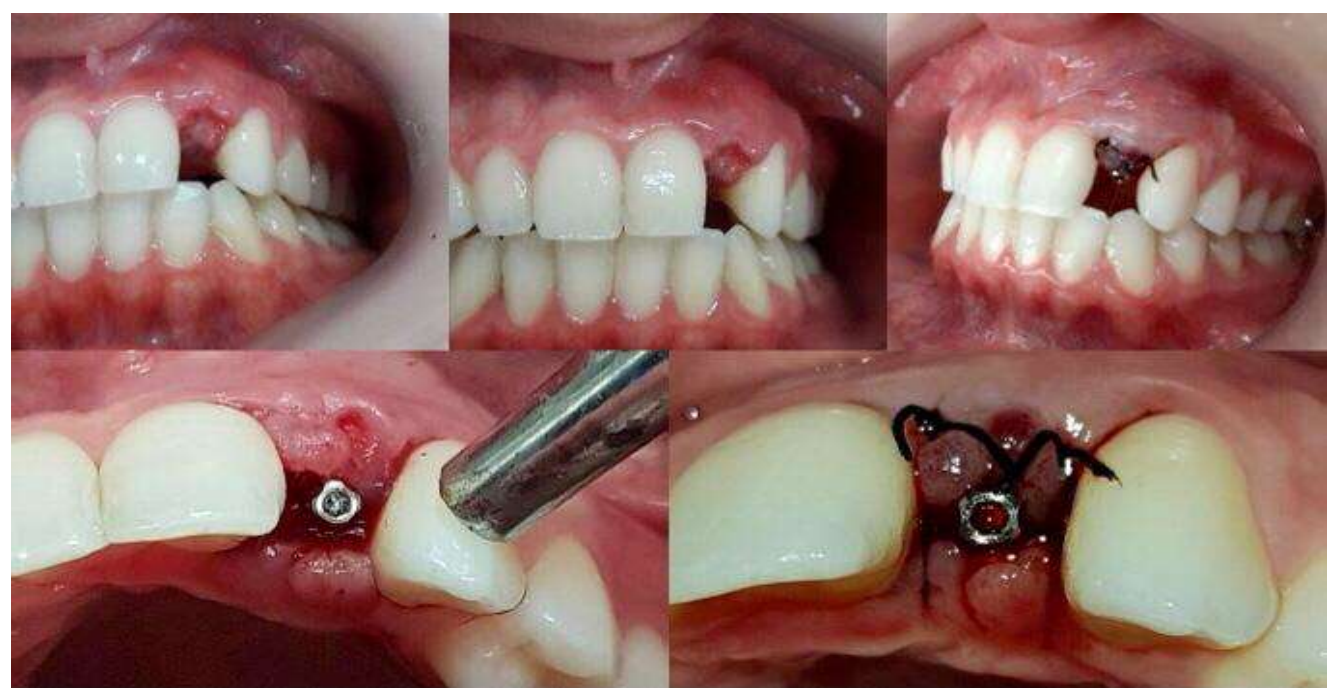

Source: Authors. 
After 4 weeks it was already possible to manipulate the soft tissue of the region. Continuing the treatment, the abutment for the provisional prosthesis was installed and then the provisional crown, as shown in Figure 6.

Figure 6 - Installation of the abutment and provisional prosthesis.

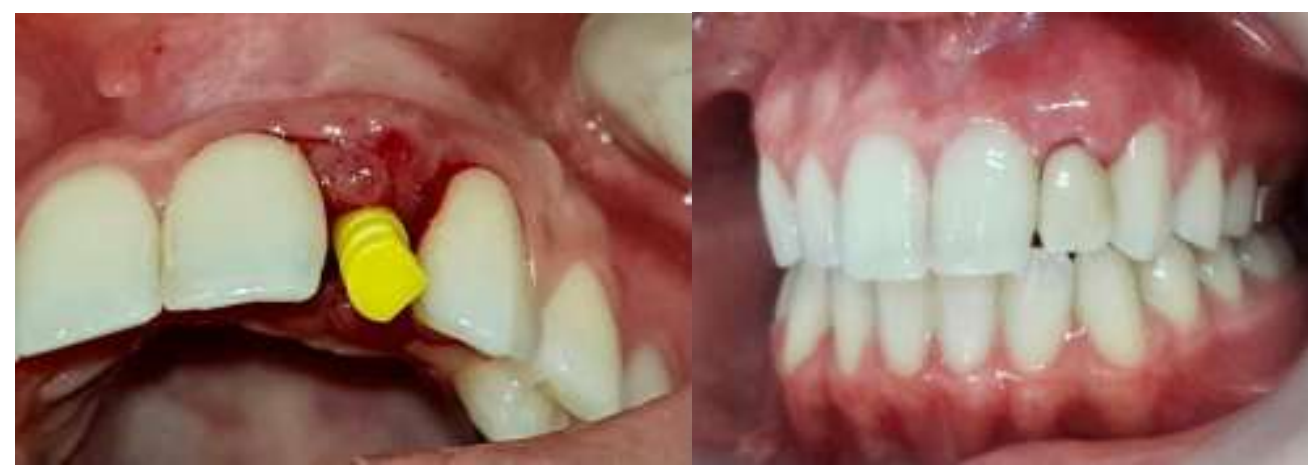

Source: Authors.

Two weeks after the installation of the provisional abutment, the patient returned with excellent healing of the region and pleasant periodontal aesthetics, as shown in Figure 7.

Figure 7- Postoperative after 2 weeks of the installation of the provisional abutment.

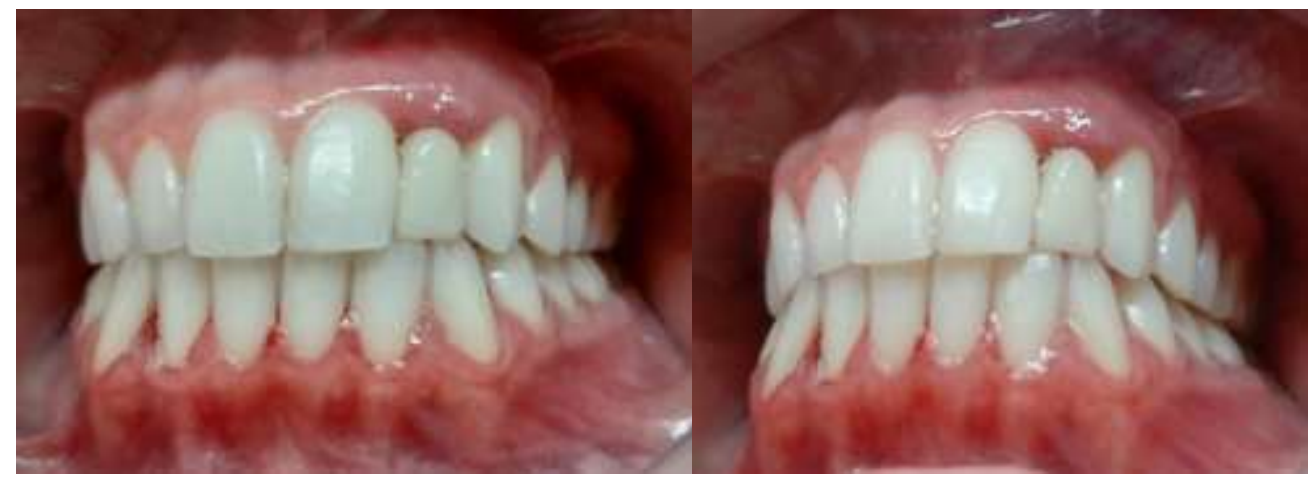

Source: Authors.

Therefore, the installation of the permanent pilare was performed (Figure 8), followed by the choice of the color of the permanent prosthesis and cementation of the permanent implant-supported prosthesis (Figure 9).

Figure 8- Definitive abutment.

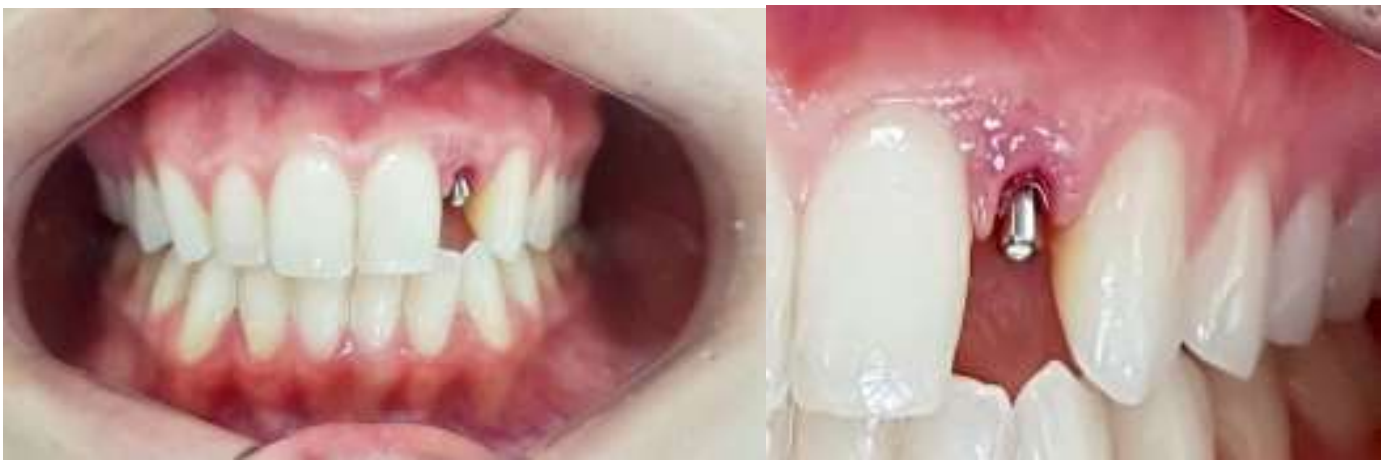

Source: Authors. 
Figure 8 shows the final abutment in position. It is also possible to observe the success of the guided bone regeneration technique through the use of biomaterials since the reconstruction of the vestibular bone region and peri-implant region showed a satisfactory prognosis, with obtaining the appropriate bone contour and gingival health as shown in the image.

Figure 9- Choice of color and installation of the definitive prosthesis.

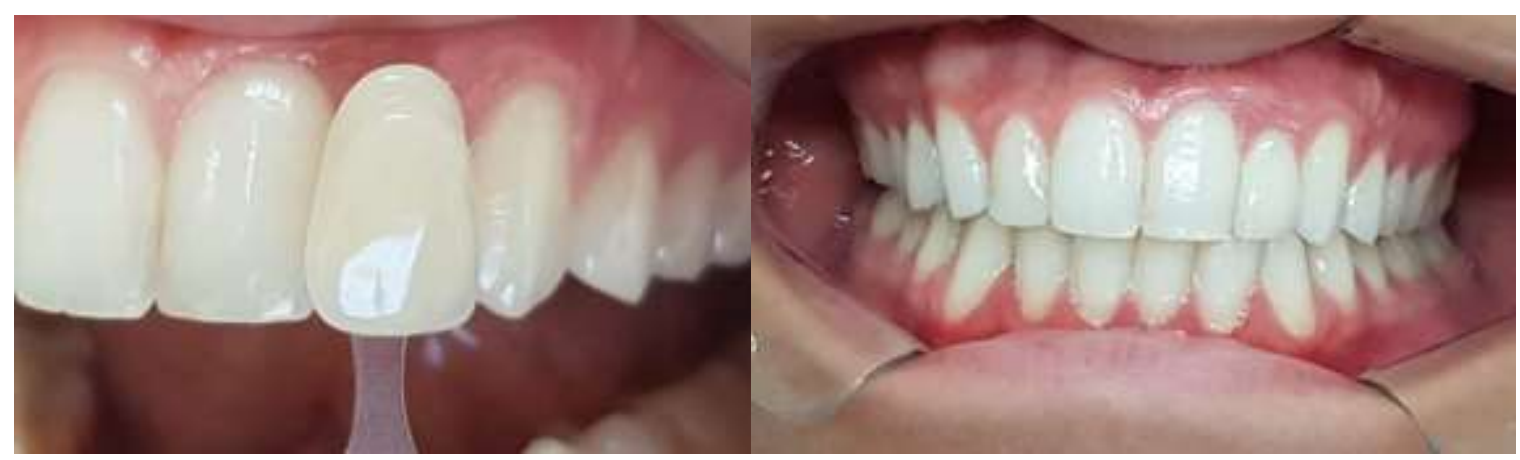

Source: Authors.

At the end of the treatment, a very satisfactory aesthetic and functional result was achieved, as shown in image 10 .

Figure 10- Final clinical aspect.
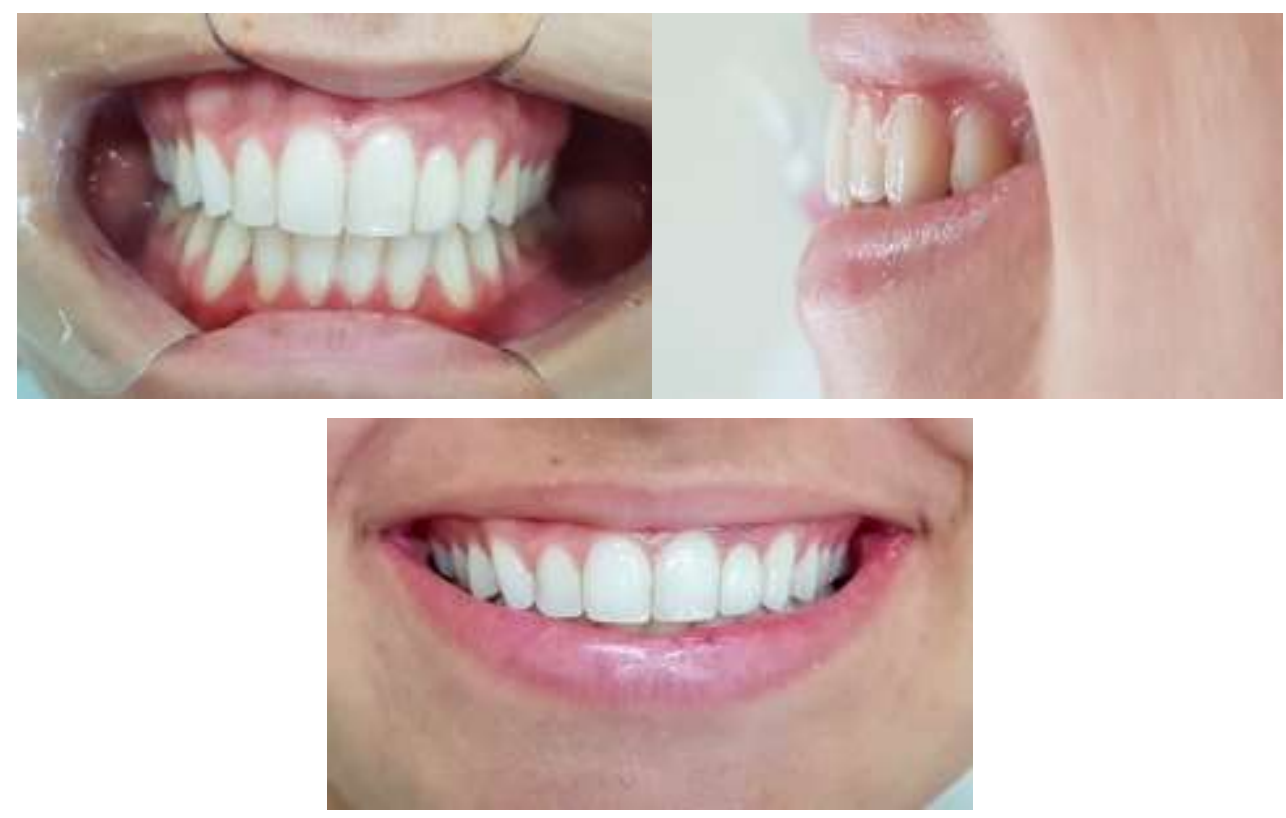

Source: Authors.

Figure 10 shows that the bone deformity of the rim has been completely eliminated. There is satisfactory keratinized tissue around the implant-supported prosthesis and adequate bone and gingival architecture. The patient presents a harmonic smile and was satisfied with the final result.

\section{Discussion}

The treatment of the absence of one or more teeth in the anterior maxillary region is considered a major challenge for the dental surgeon. The rehabilitation of edentulous patients with osseointegrated implants is recognized as a safe and 
predictable method when followed by well-established plans and the correct techniques and indications (Mazaro et al., 2014; Cosyn et al., 2011; Pilger et al., 2018).

However, the use of osseointegrated implants in cases of agenesis of the upper lateral incisor can be complex, requiring prior grafting, use of bone expanders / compactors and aesthetic abutments due to the biological, mechanical and aesthetic requirements of the region (Coelho Terra et al., 2011; Elerat et al., 2010).

Among the main difficulties that can be found in obtaining a pleasant aesthetic in previous unitary implants is the presence of bone defects in the alveolar process, which ends up making it difficult to place the implant in the ideal prosthetic position, thus requiring the professional to use reconstructive techniques to obtain the appropriate contour of the alveolar ridge (Salmen et al., 2017).

The minimum ideal bone conditions for the installation of implants are $10 \mathrm{~mm}$ of bone height and $1 \mathrm{~mm}$ of bone in width on both sides of the implant (Cabezas-Mojón et al., 2012). The installation of implants in areas with reduced bone quantity can cause major aesthetic and functional defects after prosthetic rehabilitation (Salmen et al., 2017; Cabezas-Mojón et al., 2012).

The implants must be positioned in order to preserve at least $2 \mathrm{~mm}$ of buccal bone thickness. The maintenance of a satisfactory vestibular bone volume is responsible for the long-term stability of the bone crest and gingival margin, avoiding undesirable disorders, such as exposure of the prosthetic component, or even the implant threads (Xavier et al., 2018).

The evolution in the development of biomaterials has revolutionized this therapeutic modality, facilitating the clinical resolution of cases with tissue deficiencies. In order to decrease the surgical morbidity of autogenous grafts, several companies have developed bone substitute biomaterials that associated with good planning and adequate surgical technique enable significant gains in bone quantity and quality (Pilger et al., 2018; Miron et al., 2016; Salmen et al., 2017; Herford et al., 2011).

The success of implant rehabilitation is directly related to the bone quality of the implantation region. Bone quality is responsible for obtaining the primary stability of the implant, as well as the degree of bone-implant contact. In cases of filling the vestibulo-lingual bone plate with particulate bone, bone quality will depend on the rate of resorption of the biomaterial and its ability to stimulate bone formation (Pilger et al., 2018; Xavier et al., 2018).

Clinical studies have shown that biomaterials contribute significantly to an optimized outcome in the Guided Bone Regeneration Technique and assist in maintaining the bone height and width of the alveolar ridge, as they guarantee an osteoconductive framework (Mardas et al., 2010; Geremias et al., 2015).

Currently, Bio-Oss is among the most used and researched grafting materials in dentistry. It consists of deproteinized bovine mineral bone and has contributed significantly to guided regenerative procedures (Geremias et al., 2015).

Another factor that must be taken into account in order to obtain the clinical success of unitary implants in the anterior region, is the geometry of the implant. In our clinical case, an implant with Morse Cone geometry was used, which presents greater efficiency in the preservation of bone tissue and favorable biomechanical behavior (Mazaro et al., 2014).

\section{Final Considerations}

Osseointegrated implants are an effective alternative in the treatment of dental agenesis. However, it is essential to tailor the treatment to each case individually, often requiring reconstructive techniques with biomaterials, as well as the association with other dental specialties to optimize the final result.

In view of the above, further studies are needed in the search for the best multidisciplinary treatment protocol in cases of dental agenesis so that it is possible to offer health, comfort and aesthetics to patients. 


\section{References}

Cabezas-Mojón, J., Barona-Dorado, C., Gómez-Moreno, G., Fernández-Cáliz, F., \& Martínez-González, J. M. (2012). Meta-analytic study of implant survival following sinus augmentation. Med Oral Patol Oral Cir Bucal, 17(1), 135-139.

Chen, S. T., \& Buser, D. (2014). Esthetic outcomes following immediate and early implant placement in the anterior maxilla - a systematic review. Int J Oral Maxillofac Implants, 29 Suppl, 186-215.

Coelho Terra, G. T., \& Domingos, V. B. T. C. (2011). Prótese livre de metal sobre implante osseointegrado em agenesia de incisivo lateral superior. Journal of Biodentistry and Biomaterials - Universidade Ibirapuera São Paulo, 1(1),68-75.

Cosyn, J., Eghbali, A., De Bruyn, H., Collys, K., Cleymaet, R., \& De Rouck, T. (2011). Immediate single-tooth implants in the anterior maxilla: 3-year results of a case series on hard and soft tissue response and aesthetics. J Clin Periodontol., 38(8), 746-53.

Elerat, E. L., \& Assis, M. P. (2010). Agenesia de incisivos laterais superiores - Tratamento multidisciplinar. Revista Implantnews, 7(2), 232-238.

Geremias, T. C., Montero, J. F. D., Juanito, G. M. P., Morsch, C. S., Rafael, C. F., \& Magini, R. S. (2015). Regeneração da parede vestibular em implante anterior com uso de Bio-Oss ${ }^{\circledR}$ - Relato de Caso. Full Dent. Sci., 6(24), 486-491.

Herford A. S., \& Dean, J.S. (2011). Complications in bone grafting. Oral Maxillofac Surg Clin., 23(3), 433-42.

Mardas, N., Chadha, V., \& Donos, N. (2010). Alveolar ridge preservation with guided bone regeneration and a synthetic bone substitute or a bonive-derived xenograft: a randomized, controlled clinical trial. Clin Oral Implants Res., 21(7), 688-98.

Mazaro, J. V. Q., Godoy, P. A. I., Santiago Junior, J. F. S., Mello, C. C., Pellizzer, E. P., \& Zavanelli, A. C. (2014). The guided bone regeneration in implant dentistry - case report. RFO, Passo Fundo, 19(1), 121-128.

Miron, R. J., Zhang, Q., Sculean, A., Buser, D., Pippenger, B. E., Dard, M., Shirakata, Y., Chandad, F., \& Zhang, Y. (2016). Osteoinductive potential of 4 commonly employed bone grafts. Clin Oral Investi., 20(8), 2259-2265.

Moyers, R. E. (1991) Ortodontia. (4th ed.) Rio de Janeiro.

Nagem Filho, H., Henriques, J. F. C., Couto, M. G. P., Nagem, H. D., \& Francisconi, P. A. S. (2008). Agenesia dental do incisivo lateral superior / Congenitally absent maxillary lateral incisors. Orthod. sci. pract., 1(1), 83-87.

Pereira, A. S., Shitsuka, D. M., Parreira, F. J., \& Shitsuka, R. (2018). Metodologia da Pesquisa Científica (1a ed. E-book). Santa Maria: UAB/NTE/UFSM.

Pinho, T., Tavares, P., Maciel, P., \& Pollmann, C. (2005). Developmental absence of maxillary lateral incisors in the Portuguese population. Eur J Orthod., 27(5), 443-449.

Polder, B. J., Van't Hof, M. A., Van der Linden, F. P. G. M., \& Kuijpers - Jagtman, A. M. (2004). Uma meta-análise da prevalência de agenesia dentária de dentes permanentes. Community Dentistry and Oral Epidemiology, 32(3), 217-226.

Salgado, A., Mesquita, P., \& Afonso, A. (2012). Agenesia do incisivo lateral superior - a propósito de um caso clínico. Rev Portuguesa de Estomatologia, Medicina Dentária e Cirurgia Maxilofacial, 53(3), 165-169.

Pilger, A. D., Schneider, L. E., Silva, G. M., Schneider, K. C. C., \& Smidt, R. (2018). Biomateriais de substituição óssea para procedimentos de reconstrução alveolar em implantodontia. Rev. Ciênc. Méd. Biol., 17(1), 102-107.

Salmen, F. S., Oliveira, M. R., Gabrielli, M. A. C., Piveta, A. C. G., Pereira Filho, V. A., \& Gabrielli, M. F. R. (2017). Enxerto ósseo para reconstrução alveolar. Revisão de 166 casos. Rev. Col. Bras. Cir., 44(1), 033-040.

Tanaka, O., Thibes, R., Trannin, P., Mattos, B. M., \& Miranda de Araújo, C. (2012). Um singular caso de agenesia de incisivos laterais superiores e segundo pré-molar superior esquerdo. A unique case of lateral incisors and second left bicuspid agenesis. Orthodontic Science and Practice, 5(19), 347-354.

Tsuda, H., Rungcharassaeng, K., Kan, J. Y., Roe, P., Lozada, J. L., \& Zimmerman, G. (2011). Peri-implant tissue response following connective tissue and bone grafting in conjunction with immediate single-tooth replacement in the esthetic zone: a case series. Int J Oral Maxillofac Implants, 26(2), 427-36.

Xavier, S. F., Formiga, M., Borges, I., \& Melo, B. F. (2018). Aumento ósseo horizontal com biomaterial para colocação de implantes osseointegráveis em mandíbula atrófica-Três anos de acompanhamento. I NPerio, 3(4), 662-72. 